\title{
Prolonged low dose indomethacin for persistent ductus arteriosus of prematurity
}

\author{
Department of \\ Paediatrics, \\ Level 8, \\ Addenbrooke's Hospital, \\ Hills Road, \\ Cambridge CB2 200 \\ Janet M Rennie \\ Department of \\ Child Health \\ University of Liverpool \\ Richard W I Cooke \\ Correspondence to: \\ Dr Rennie.
}

Accepted 10 May 1990

\begin{abstract}
A total of 121 infants who required indomethacin for persistent ductus arteriosus in Liverpool and Cambridge over a four year period were randomised to receive either 0.1 $\mathrm{mg} / \mathrm{kg}$ daily for six days or $0.2 \mathrm{mg} / \mathrm{kg}$ every 12 hours for three doses. The groups were of similar birth weight and gestational and postnatal age, though those treated with a low dose were by chance receiving a higher percentage of oxygen at the start of treatment and there were more deaths from bronchopulmonary dysplasia in this group. Of 59 infants treated with the prolonged course $53(90 \%)$ responded initially to indomethacin compared with 48 of $62(77 \%)$ treated conventionally-a difference of $13 \%$ ( $95 \%$ confidence interval for the difference 0 to 26\%). Of the 53 responders $11(21 \%)$ relapsed after low dose indomethacin, whereas after the shorter course 19 of 48 (40\%) relapsed. This difference was significant $(95 \%$ confidence intervals 3 to $37 \%)$. Side effects, mainly gastrointestinal haemorrhage, were similar in both groups. Significantly fewer infants experienced a rise in serum creatinine or urea concentration after treatment with low dose indomethacin. A prolonged low dose course of indomethacin offers advantages over conventional treatment.
\end{abstract}

Several double blind trials have shown that indomethacin is capable of reducing left to right shunt through a persistent ductus arteriosus in preterm infants. ${ }^{12}$ The success rate after treatment is between 60 and $80 \%$, with a relapse rate of about $30 \% .^{3-5}$ The observation that infants treated at greater postnatal age seemed to respond less well, ${ }^{6}$ resulted in studies of early treatment either as prophylaxis given to a cohort on the basis of birth weight, ${ }^{7-9}$ or after identification of shunting with an early aortogram or contrast echocardiography. 10 il Prophylactic indomethacin reduced subsequent ductal shunting, but as only $30 \%$ of a very low birthweight cohort develop an important left to right shunt, many would consider that the risk of side effects outweighs any potential benefit. Early treatment (at a mean of 2.9 days, as soon as any clinical signs were detected) was associated with a reduction in the amount of oxygen needed by those weighing less than $1000 \mathrm{~g}$ in one study, ${ }^{12}$ but this has not always been confirmed and one small trial has recently shown the opposite. ${ }^{13}$

Pharmacokinetic studies have also been used in attempts to improve the response to indomethacin. These have shown that the absorption is erratic after enteral administration, ${ }^{14}$ and that even after an intravenous dose plasma concentrations vary 20 -fold and overwhelm any differences in half life and clearance related to postnatal and gestational age. ${ }^{15}$ In general the response of the ductus and the side effects of indomethacin do not correlate well with the plasma indomethacin concentration. ${ }^{16}{ }^{17}$ Brash et al proposed a threshold of 250 $\mathrm{ng} / \mathrm{ml}$ and noted that relapse occurred on about the fifth day when concentrations of indomethacin had fallen to about $50 \mathrm{ng} / \mathrm{ml} .{ }^{15}$ Seyberth et al used on line monitoring, and thought that a plasma concentration of $1000 \mathrm{ng} / \mathrm{ml}$ may be needed for as long as a week. ${ }^{18}$ Our previous work showed, however, that five of the seven infants who had gastrointestinal bleeds were among the seven with concentrations above $1000 \mathrm{ng} / \mathrm{ml}$ at any time. ${ }^{7}$ In further trials Seyberth et al have initiated treatment starting with indomethacin concentrations of $1000 \mathrm{ng} /$ $\mathrm{ml}$ and continuing at $150-750 \mathrm{ng} / \mathrm{ml} .^{19}$

Inhibition of prostaglandin synthesis can be achieved even with low plasma concentrations of indomethacin in the newborn, ${ }^{7}$ as well as in adults. ${ }^{20}$ This may explain the poor correlation between response and plasma concentrations. Both plasma and urinary prostaglandin synthesis returns about five days after indomethacin has been stopped, ${ }^{72}$ corresponding to the time at which indomethacin concentrations are falling and possibly thereby contributing to failure of treatment. These results have led to trials of prolonged low dose indomethacin, ${ }^{22}{ }^{23}$ which appears to be safe. ${ }^{18}$ In the study we compared prolonged low dose indomethacin with three higher doses at intervals of 12 hours in infants requiring treatment for left to right shunt due to persistent ductus arteriosus that had been diagnosed clinically.

\section{Patients and methods}

Babies weighing less than $2500 \mathrm{~g}$ at birth who developed clinical signs of persistent ductus arteriosus that required treatment with indomethacin were enrolled in Liverpool and Cambridge. Treatment was allocated by opening a sealed envelope randomising the baby to receive either a six day course of $0.1 \mathrm{mg} / \mathrm{kg}$ or three doses at intervals of 12 hours of $0.2 \mathrm{mg} / \mathrm{kg}$. The course was completed unless treatment was stopped because of a complication. Information on the subsequent course was collected prospectively; relapse was defined as a recurrence of systolic murmur and increased pulse volume. Between September 1985 and July 1989, 123 babies were enrolled; one was excluded because 
of a diagnosis of hydrops fetalis, and another because the course was stopped after an incorrect prescription of $1.0 \mathrm{mg} / \mathrm{kg}$. The trial was approved by the ethics committees of both hopitals.

POWER

The study design allowed us to examine two end points: response to treatment and relapse after treatment. From the results of previous work, about $70 \%$ of babies could be expected to respond to indomethacin with a relapse rate of $30 \% .{ }^{4}$ Assuming that an improvement in the response rate to $90 \%$ might occur, a formula was used to calculate numbers. ${ }^{24}$ Calculating the formula for alpha $=0.05$-that is, for a $5 \%$ chance of rejecting the null hypothesis and detecting a difference in treatments when none exists-and beta $=0.2$ - giving a $20 \%$ chance of committing a type II error and failing to detect a true difference-a total of 122 babies would be needed. The power of the study with this number of babies would be $80 \%$. A similar calculation using the sample size tables of Fleiss ${ }^{25}$ results in a total of 142 babies for $80 \%$ power, but Pocock ${ }^{26}$ has pointed out that these tables are designed for the analysis to be done using $\chi^{2}$ with Yates's correction and that if this is not necessary then the numbers are an overestimate.

For the end point of relapse, in order to detect a reduction in the relapse rate from the expected figure of $30 \%$ to $15 \%$ with $80 \%$ power 192 babies would be needed: 122 babies gives only $65 \%$ power, and therefore a $35 \%$ chance of failing to detect a true difference.

STATISTICAL ANALYSIS

To analyse the results we used the statistical package for the social sciences (SPSS). ${ }^{27}$ The $\chi^{2}$ test was used for comparison of groups, and Student's $t$ test or the Mann-Whitney U test where appropriate. Results are also reported with calculation of $95 \%$ confidence intervals (CI) as suggested by Gardner and Altman. ${ }^{28}$

\section{Results}

RESPONSE AND RELAPSE

The treatment groups were well matched for birth weight and gestational age, and there were no differences between centres or in the postnatal age at which the babies received treatment (table 1). Of 59 babies, 53 responded to the low dose course (90\%) compared with 48 of 62 (77\%) after a conventional course (table 2 ). This represents a treatment difference of $13 \%$ with ( $95 \%$ CI 0 to $\left.26 \%, \chi^{2} 4.32, p=0.06\right)$. Eleven of the 53 babies who responded to the prolonged course subsequently relapsed $(21 \%)$ compared with 19 of 48 after the conventional course $(40 \%)$; the difference between treatments was $19 \%\left(95 \%\right.$ CI 3 to $\left.37 \%, \chi^{2}=4 \cdot 28, p<0.05\right)$. Three of these babies required ductal ligation. The results are shown graphically in the figure, together with the treatment differences and $95 \%$ CI for the other clinically relevant outcomes.

\section{SIDE EFFECTS}

There was no significant difference in side effects recorded during the administration of indomethacin, with 10 and 13 babies, respectively, experiencing any side effect that was possibly due to treatment; most of these were gastrointestinal haemorrhages. Treatment was stopped in a total of eight babies: two had gastrointestinal perforations after a conventional course of treatment and required ductal ligation because of treatment failure; six had

Table 1 Comparison of 59 babies treated with prolonged low dose of indomethacin and 62 treated with conventional dose

\begin{tabular}{|c|c|c|c|c|}
\hline & \multicolumn{2}{|l|}{ Indomethacin } & \multirow{2}{*}{$\begin{array}{l}\text { Statistical } \\
\text { test }\end{array}$} & \multirow{2}{*}{$\stackrel{p}{\text { Value }}$} \\
\hline & $\begin{array}{l}0 \cdot 1 \mathrm{mg} / \mathrm{kg} \times 6 \\
(\text { low dose })\end{array}$ & $\begin{array}{l}0.2 \mathrm{mg} / \mathrm{kg} \times 3 \\
(\text { conventional dose })\end{array}$ & & \\
\hline $\begin{array}{l}\text { Mean (SD) birth weight (g) } \\
\text { Mean (SD) gestational age (weeks) }\end{array}$ & $\begin{aligned} 1116(340) \\
27(2 \cdot 2)\end{aligned}$ & $\begin{array}{r}1135(340) \\
27(2 \cdot 2)\end{array}$ & $\begin{array}{l}t \text { Test } \\
t \text { Test }\end{array}$ & $\begin{array}{l}0.71 \\
0.72\end{array}$ \\
\hline $\begin{array}{l}\text { Centre: } \\
\text { Liverpool } \\
\text { Cambridge }\end{array}$ & $\begin{array}{l}23 \\
36\end{array}$ & $\begin{array}{l}32 \\
30\end{array}$ & $\chi^{2}$ & $0 \cdot 2$ \\
\hline $\begin{array}{l}\text { Time treated: } \\
\text { Postnatal age }<7 \text { days } \\
\text { Postnatal age } \geqslant 7 \text { days } \\
\text { Median (interquartile range) maximum } \\
\text { oxygen concentration day } 1\end{array}$ & $\begin{array}{l}32 \\
27 \\
40(30-60)\end{array}$ & $\begin{array}{l}39 \\
23 \\
30(25-45)\end{array}$ & Mann-Whitney & $0 \cdot 43$ \\
\hline
\end{tabular}

Table 2 Outcome after treatment with either prolonged low dose of indomethacin $(n=59)$ or conventional course ( $n=62)$. Results are given as number (\%) of babies

\begin{tabular}{|c|c|c|c|c|}
\hline & \multicolumn{2}{|l|}{ Indomethacin } & \multirow[t]{2}{*}{$\chi^{2}$} & \multirow{2}{*}{$\stackrel{p}{\text { Value }}$} \\
\hline & $\begin{array}{l}0.1 \mathrm{mg} / \mathrm{kg} \times 6 \\
(\text { low dose })\end{array}$ & $\begin{array}{l}0.2 \mathrm{mg} / \mathrm{kg} \times 3 \\
(\text { conventional dose })\end{array}$ & & \\
\hline $\begin{array}{l}\text { Response } \\
\text { Relapse } \\
\text { Retreated } \\
\text { Side effects } \\
\text { Rise in serum urea or creatinine }\end{array}$ & $\begin{array}{l}53(90) \\
11(21) \\
10(19) \\
10(17)\end{array}$ & $\begin{array}{l}48(77) \\
19(40) \\
11(23) \\
13(21)\end{array}$ & $\begin{array}{l}3 \cdot 37 \\
4 \cdot 28 \\
0 \cdot 25 \\
0 \cdot 32\end{array}$ & $\begin{array}{l}0 \cdot 06 \\
0.04 \\
0 \cdot 62 \\
0 \cdot 57\end{array}$ \\
\hline $\begin{array}{l}\text { Reduction in inspired oxygen at } 6 \text { days } \\
\text { Died }\end{array}$ & $\begin{array}{l}17(29) \\
34(68) \\
10(17)\end{array}$ & $\begin{aligned} 33 & (53) \\
21 & (34) \\
3 & (5)\end{aligned}$ & $\begin{array}{l}6.68 \\
6.60 \\
4.62(3 \cdot 44)^{*}\end{array}$ & $\begin{array}{l}0.009 \\
0.009 \\
0.03(0.06)^{*}\end{array}$ \\
\hline
\end{tabular}

*These results are with (and without) Yates's correction. 


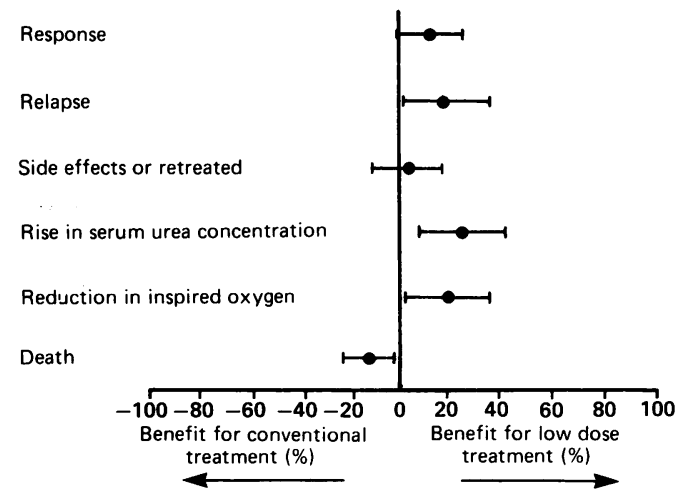

Differences in treatment and $95 \%$ confidence intervals of differences in outcomes.

bleeding complications; and two went into acute renal failure (short course). Significantly fewer babies had any rise in serum urea or creatinine concentrations after treatment with the low dose regimen: $29 \%$ compared with $53 \%\left(\chi^{2} 6 \cdot 68\right.$, $\mathrm{p}=0.009$ ) (table 2).

\section{DEATHS}

There were significantly more deaths after the long course: 10 of $52(17 \%)$ compared with three of $62(5 \%)(p=0.03)$. Only two of the deaths occurred during the first month of life. One was after intensive care had been withdrawn because of periventricular leucomalacia and periventricular haemorrhage in a severely ill baby, and the second was due to persistent pulmonary hypertension, possibly related to showers of platelet emboli (seen at necropsy) from a umbilical catheter that was rather high. This baby had received only one dose of indomethacin, as the platelet count fell rapidly over the first few days. Five of the remaining eight deaths in the long course group were at several months of age of bronchopulmonary dysplasia, the remaining three being from sepsis at about 1 month of age. The remaining deaths in the short course group were due to a late cot death and bronchopulmonary dysplasia. Thus no deaths could be directly attributed to treatment, and the higher incidence of deaths from bronchopulmonary dysplasia in the group receiving the long course may reflect the fact that the babies were receiving a significantly higher percentage of oxygen at the start of treatment: median $40 \%$ (interquartile range 30 to $60 \%$ ) and $30 \%$ ( 25 to $45 \%$ ).

\section{SUBGROUP INFORMATION}

Analysing subgroups of babies treated at less than or greater than one week postnatal age and who were less than or greater than 28 weeks' gestation or weighed less than $1000 \mathrm{~g}$ also showed no significant differences in outcome. Initial response to treatment was between $68 \%$ and $92 \%$, the best response being in babies of less than 1 week postnatal age treated with a long course. A good response was also achieved, however, at a postnatal age of greater than 1 week in 39 babies. Babies of gestational age less than 28 weeks or birth weight less than $1000 \mathrm{~g}$ responded well to treatment without the increase in side effects described in some studies.

\section{Discussion}

Relapse after functional closure of the persistent ductus arteriosus with indomethacin has been a problem since the early days. Attempts at limiting side effects have resulted in a reduction of the dose by some 10-fold from that used originally in the newborn and prescribed for adult patients. ${ }^{29}$ Indomethacin is an extremely powerful prostaglandin synthetase inhibitor and because prostaglandins are widely distributed and involved in the control of the microcirculation throughout the body the drug has widespread effects. Perhaps the most important of these in preterm babies are those regulating the renal and cerebral circulations. Studies examining the effect of indomethacin on cerebral blood flow velocity have consistently shown a reduction. ${ }^{30} 31$ Although some workers have suggested that this may be of benefit in the prophylaxis of periventricular haemorrhage, ${ }^{32}$ this is not a consistent finding. ${ }^{33}$ Few long term follow up studies have been reported: low cerebral blood flow may be detrimental in the immediate postpartum period. Most of the evidence, therefore, is against the use of prophylactic indomethacin and more studies of the type reported here are needed in order to establish the best timing, duration, and dose, if the drug is to be used effectively in a 'rescue' fashion.

In this study we examined the effects of the same total dose of indomethacin given in two different ways. There was a trend towards an improvement in the initial response rate after the prolonged course, with $95 \%$ CI for the difference in response compared with a conventional short course falling between no fewer responses and $25 \%$ more closures. The high relapse rate often reported after indomethacin probably results from a resurgence of prostaglandin synthesis and makes prolonged treatment logical. ${ }^{721}$ The results showed a significant difference in relapse rate although the risk of a type II error was high. Few of the relapses noted in this study were thought to be important enough to require retreatment or to require an increase of ventilatory support.

The increase in mortality after a prolonged course has not been reported before, and although it was probably explained by the highly significant difference in inspired oxygen concentration at the start of treatment in this group, the observation reminds us of the need to evaluate new treatments carefully and to sound a note of caution. The concern about impaired renal function in babies receiving prolonged indomethacin has not been supported by this study-in which there were fewer babies who experienced a rise in serum creatinine or urea concentrations after treatment-or by other work. ${ }^{18}$ Relatively large numbers of infants weighing less than $1000 \mathrm{~g}$ at birth were treated, and responded equally well to indomethacin as those of higher birth weights.

Prolonged low dose indomethacin offers an 
alternative effective way of achieving reduction of left to right shunt in babies in whom a clinical diagnosis of persistent ductus arteriosus has been made. Prolongation of treatment improves the initial response and reduces the relapse rate.

We thank our colleagues Dr M Weindling, Dr NRC Roberton, and Dr C Morley for allowing us to include their patients in this study, and the medical and nursing staff of the neonatal units in the Rosie Maternity Hospital, Cambridge, and the Liverpool Maternity Hospital. Merck, Sharpe and Dohme kindly provided indomethacin for the study.

1 Rudd $\mathrm{P}$, Montanez $\mathrm{P}$, Hallidie-Smith $\mathrm{K}$, Silverman $M$ Indomethacin treatment for patent ductus arteriosus in Indomethacin treatment for patent ductus arteriosus in very low birth weight

2 Yeh TF, Luken JA, Thalji A, Raval D, Carr I, Pildes RS Intravenous indomethacin therapy in premature infants with PDA. I Pediatr 1981;98:131-5.

3 Ramsay JM, Murphy DJ, Vick GW, Courtney JT, GarciaPrats JA, Huhta JC. Response of the PDA to indomethacin. Am F Dis Child 1987;141:294-7.

4 Gersony WM, Peckham GJ, Ellison RC, Miettinen OS Nadas AS. Effects of indomethacin in premature infants with patent ductus arteriosus: results of a national collaborative study. I Pediatr 1983;102:895-905.

5 Mellander M, Lehup B, Lindstrom DP, et al. Recurrence of symptomatic PDA in premature infants treated with indomethacin. F Pediatr 1984;105:138-43.

6 Firth J, Pickering D. Timing of indomethacin therapy in PDA. Lancet 1980;ii: 144.

7 Rennie JM, Doyle J, Cooke RWI. Early administration of indomethacin to preterm infants. Arch Dis Child 1986;61:233-8.

8 Mahoney L, Caldwell RL, Girod DA, et al. Indomethacin therapy on the first day of life in infants with very low therapy on the first day of life in infants

9 Kreuger E, Mellander M, Bratton D, Cotton R. Prevention of symptomatic patent ductus arteriosus with a single dose of indomethacin 7 Pediatr 1987;111:749-54.

10 Kaapa P, Lanning P, Koivisto M. Early closure of PDA with indomethacin in preterm infants with respiratory distress syndrome. Acta Paediatr Scand 1983;72:179-84.

11 Hammerman C, Strates C, Valtaitis S. The silent ductus: its precursors and its aftermath. Pediat Cardiol 1986;7:121-5.

12 Mahony L, Carnero V, Brett C, Heymann M, Clyman RI. Prophylactic indomethacin therapy for PDA in very low birthweight infants. $N$ Engl $\mathcal{F}$ Med 1982;306:506-10.

13 Vincer M, Evans AL, Nwaesi C, et al. Early intravenous indomethacin prolongs respiratory support in very low

14 Bhat $R$, Vidayasagar D, Vadapalli $M$, et al. Disposition of indomethacin in preterm infants. $\mathcal{f}$ Pediatr 1987;95:313-6.
Brash AE, Hickey DE, Graham TP, Stahlman MT, Oates JA, Cotton RB. Pharmacokinetics of indomethacin in the neonate. N Engl f Med 1981;305:67-72.
16 Alpert BS, Lewins MJ, Rowland DW, et al. Plasma indomethacin levels in preterm newborns with symptomatic patent ductus arteriosus: clinical and echocardiographic assessments of response. $\mathcal{J}$ Pediatr 1979;95:578-82.

17 Vert P, Bianchetti G, Marchal F, Monin P, Morselli PL. Effectiveness and pharmocokinetics of indomethacin in premature newborns with patent ductus arteriosus. Eur $\mathcal{f}$ Clin Pharmacol 1980;18:83-8.

18 Seyberth HW, Knapp G, Wolf D, Ulmer HE. Introduction of plasma indomethacin level monitoring and evaluation of an effective threshold level in VLBWI with symptomatic PDA. Eur f Pediatr 1983;141:71-6.

19 Seyberth HW, Rascher W, Hackenthal R, Willie L. Effect of prolonged indomethacin therapy on renal function and selected vasoactive hormones in VLBWI with symptomatic patent ductus arteriosus. F Pediatr 1983;103:979-84.

20 Rane A, Oelz O, Frolich JC, et al. Relation between plasma concentration of indomethacin and its effect on prostaglandin synthesis and platelet aggregation in man. Clin Pharmacol Ther 1978;23:127-41.

21 Seyberth HW, Mudieresisller H, Wille L, Pludieresisckthun H, Wolf D, Ulmer HE. Recovery of prostaglandin producH, Wolf D, Ulmer HE. Recovery of prostaglandin production associated with reopening of the ductus arteriosus after indomethacin therapy in preterm infants with respirator

22 Leonhardt A, Isken V, Kudieresishl PG, Seyberth HW. Proonged indomethacin therapy in preterm infants with symp omatic patent oring and patient selection. Eur f Pediatr 1987;146:140-4.

23 Rhodes PG, Ferguson MG, Reddy NS, Joransen JA, Gibso J. Effects of prolonged versus acute indomethacin therapy in very low birthweight infants with patent ductus arteriosus. Eur f Pediatr 1988;147:481-4.

24 Friedman LM, Furberg CD, DeMeto DL. Sample size. Fundamentals of clinical trials. Littleton: PSG, 1985: 83-107.

25 Fleiss JL. Statistical methods for rates and proportions. Chichester: Wiley, 1981.

26 Pocock SJ. The size of clinical trials. Clinical trials: a practical approach. Chichester: Wiley, 1983:127.

27 SPSSX User's guide. 2nd Ed New York: McGraw Hill, 1986.

28 Gardner MJ, Altman DG. Confidence intervals rather than values: estimation rather than hypothesis testing. $B M \mathcal{F}$ values: estimation

29 Friedman WF, Hirschklan MJ, Printz MP, Pitlick PT, Kirkpatrick SE. Pharmacological closure of patent ductus arterosus in the premature infant. $N$ Engl F Med 1981;305:52639.

30 Cowan F. Indomethacin, patent ductus arteriosus and cerebral blood flow. F Pediatr 1986;109:341-2.

31 Evans DH, Levene MI, Archer LNJ. Effect of indomethacin on cerebral blood flow velocity in premature infants. Dev Med Child Neurol 1987;29:776-82.

32 Ment LR, Duncan CC, Ehrenkrantz RA, et al Randomised ow-dose indomethacin trial for prevention of intraventricuar haemorrhage in very low birthweight neonates. 7 Pediatr 1988;112:948-55.

33 Hanigan WC, Kennedy G, Roemisch F, Anderson R, Cucksak T, Powers W. Administration of indomethacin for the prevention of intraventricular haemorrhage in high risk prevention of intraventricular haem
neonates. F Pediatr 1988;112:941-7. 